\title{
Molecular characterization of Histoplasma capsulatum isolated from an outbreak in treasure hunters
}

Bertha Muñoz ${ }^{1}$, María Á Martínez², Gabriel Palma', Amado Ramírez ${ }^{1}$, María G Frías ${ }^{3}$, María R Reyes ${ }^{3}$, María L Taylor ${ }^{4}$, Anjarath L Higuera ${ }^{5}$, Alexander Corcho ${ }^{5}$, María E Manjarrez ${ }^{1 *}$

\begin{abstract}
Background: In Mexico, primary pulmonary histoplasmosis is the most relevant clinical form of the disease. The geographical distribution of specific strains of Histoplasma capsulatum circulating in Mexico has not been fully established. Outbreaks must be reported in order to have current, updated information on this disease, identifying new endemic areas, manner of exposure to the fungi, and molecular characterization of the causative agents. We report a recent outbreak of histoplasmosis in treasure hunters and the molecular characterization of two isolates obtained from these patients.
\end{abstract}

Methods: Six patients admitted to the National Institute of Respiratory Diseases (INER) in Mexico City presented severe respiratory symptoms suggestive of histoplasmosis. They acquired the infection in the Veracruz (VZ) endemic zone. Diagnosis was made by X-ray and Computed tomography (CT), liver function, immunological techniques, and culture. Identification of $\mathrm{H}$. capsulatum isolates was confirmed by using Polymerase chain reaction (PCR) was conducted with a probe from the $M$ antigen, and the isolates were characterized by means of Random amplification of polymorphic DNA (RAPD)-PCR employed the 1253 oligonucleotide and a mixture of oligonucleotides 1281 and 1283. These were compared to eight reference strain isolates from neighboring areas.

Results: X-ray and CT revealed disseminated micronodular images throughout lung parenchyma, as well as bilateral retrocaval, prevascular, subcarinal, and hilar adenopathies, hepatosplenomegaly, and altered liver function tests. Five of the six patients developed disseminated histoplasmosis. Two H. capsulatum strains were isolated. The same band profile was detected in both strains, indicating that both isolates corresponded to the sole H. capsulatum strain. Molecular characterization of the isolates was similar in $100 \%$ with the EH-53 Hidalgo human (HG) strain (reference strain integrated into the LAm A clade described for Latin America).

Conclusions: The two isolates appeared to possess the same polymorphic pattern; they are indistinguishable from each other and from EH-53. It is important to remain updated on recent outbreaks of histoplasmosis, the manner of exposure to the fungi, as well as the molecular characterization of the isolates. The severity of cases indicates that this strain is highly virulent and that it is probably prevalent in Hidalgo and Veracruz states.

\footnotetext{
* Correspondence: e_manjarrez@yahoo.com

'Laboratorio de Micología Médica, Depto. de Investigación en Virología, Instituto Nacional de Enfermedades Respiratorias (INER), Calzada de Tlalpan 4502, Sección XVI, Tlalpan,14080 México, D.F., México

Full list of author information is available at the end of the article
} 


\section{Background}

Histoplasma capsulatum develops in bird excrement or bat guano in closed areas (caves, mines, tunnels) or in open spaces (parks, orchards, and abandoned homes, among others). The organic material found in these waste materials under humid conditions and optimal temperatures establishes the ecological niche for the mycelial phase of development, and microconidium constitutes the infectious form of the fungus [1-3]. There have been three distinct genotypes and varieties of $H$. capsulatum, and two have infected human beings: $H$. capsulatum var. capsulatum, and $H$. capsulatum var. duboisii; in addition, one has infected equines (H. capsulatum var. farciminosum). These exhibited different clinical manifestations and geographical distributions [4-6]. However, a phylogenetic study by Kasuga and colleagues $[7,8]$ was conducted in an attempt to resolve the relationships among the major classes and three varieties of $H$. capsulatum. At least eight clades were identified: (i) North American class 1 clade; (ii) North American class 2 clade; (iii) Latin American group A clade; (iv) Latin American group B clade; (v) Australian clade; (vi) Netherlands (Indonesian?) clade; (vii) Eurasian clade, and (viii) African clade. Seven of the eight clades represented genetically isolated groups that may be recognized as phylogenetic species.

This fungus is the etiological agent of systemic mycosis histoplasmosis. The mycosis is an endemic disease of tropical, subtropical, and temperate areas throughout the world. Histoplasmosis has been described as present in all of the 32 states of the Mexican Republic, with highly variable prevalence [3,9-19]. Veracruz is one of the federal entities with the greatest number of cases reported [18]. In Mexico, histoplasmosis is considered an occupational disease that especially affects miners, farmers, guano collectors, cockfight breeders, geologists, speleologists, anthropologists, and biologists. Primary pulmonary histoplasmosis ( $\mathrm{PPH})$ is the most relevant clinical form of the disease with the highest mortality rate worldwide $[10,11,18,20]$. The clinical manifestations of this mycosis may range widely, from being clinically benign to severe, even fatal, depending upon the amount of propagules inhaled, the immunological state of the infected host, and the strain's virulence [3]. It is important to report outbreaks of histoplasmosis in order to know the current status of this disease, identify new endemic areas, and for molecular characterization of the causative agents. This study reports on an outbreak of histoplasmosis in treasure hunters in the endemic zone of Veracruz and the molecular characterization of two isolates from these patients.

\section{Methods}

\section{Case studies}

Six patients (two children and four adults), one with type 2 diabetes mellitus, were admitted to the Instituto Nacional de Enfermedades Respiratorias (INER) in Mexico City in August 2007 with severe histoplasmosis-associated respiratory symptoms. On questioning, patients referred having family ties among themselves and that they were residents of Naucalpan, near Mexico City. They had traveled to the town of Tamarindos, Ciudad Cardel, Veracruz (a histoplasmosis endemic zone) (Figure 1) in a search for treasure. They had slept for 3 consecutive days in a house and also mentioned that they excavated for 2 days with constant exposure to dust, migratory bird excreta, as well as bat guano in surrounding areas.

Informed consent was obtained from patients or their parents or guardians, and the Human Experimentation Guidelines of the Institution were followed according to clinical research conduct.

\section{Isolation and identification of $\mathrm{H}$. capsulatum and detection of anti-H. capsulatum antibodies}

The specimens analyzed included bronchial washings, sputum, and blood. All samples were sent to the laboratory for immediate processing. Direct examination from specimens with $15 \%$ potassium hydroxide was performed, as well as cytological tests with methenamine silver (Grocott) and Periodic acid-Schiff (PAS) staining, in Sabouraud dextrose-agar (SDA) cultures, and SDA with antibiotics (chloramphenicol, $50 \mathrm{mg} / \mathrm{L}$, and

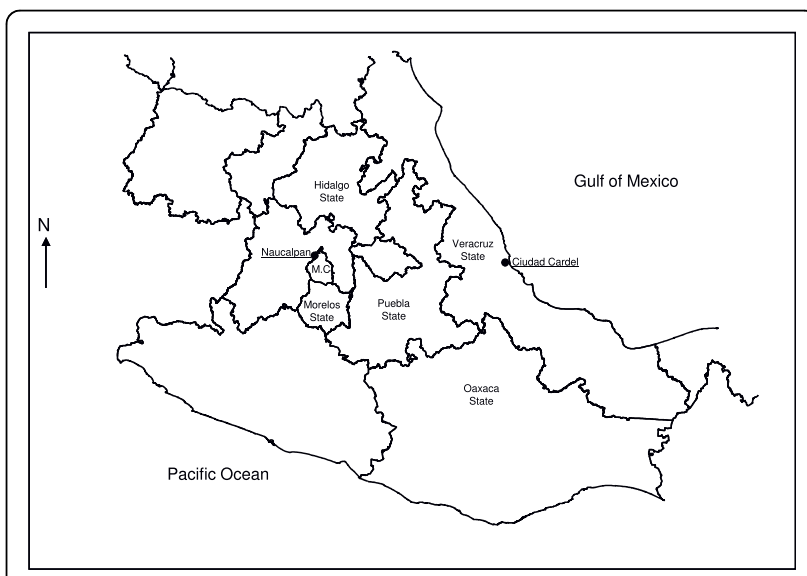

Figure 1 Ciudad Cardel, La Antigua Municipality, Veracruz, Mexico. The figure shows, the Veracruz-neighboring states, endemic areas from which isolates and type strains and, Mexico City (MC) and Naucalpan (patient's place of residence). 
cycloheximide, $500 \mathrm{mg} / \mathrm{L}$ ). Isolates were identified on the basis of colonial and microscopic morphology. Serological tests for anti-H. capsulatum antibodies included Capillary tube precipitation (CTP) [21], gel Immunodiffusion (ID) [22-24], and the indirect Enzyme linked immunosorbent assay (ELISA) method according to Voller et al. [25]. Immune cell response was assessed by means of skin testing; this method evaluates the reactivity of the patients to histoplasmin. Changes observed in lungs, liver, and spleen were assessed utilizing $\mathrm{X}$-rays and CT scans.

\section{Molecular identification and characterization of isolates}

Molecular typing of the two isolates was performed employing Polymerase chain reaction (PCR). H. capsulatum reference strains were used from Mexican patients with disseminated histoplasmosis: EH-53 from Hidalgo (HG) and EH-317 human from Morelos (MS), and the following isolates from infected bats: EH-397 Pterotus davyi, and EH-398 Leptonycteris curasoae from Oaxaca (OC); EH-406 Leptonycteris novalis and EH-408 Leptonycteris novalis from Puebla (PL), and EH-437 Desmodus rotundus and EH-449 Leptonycteris novalis from Morelos (MS), all of these areas located near the state of Veracruz. All of these strains are labeled as follows: "Histoplasma capsulatum Strain Collection of the Fungal Immunology Laboratory of the Department of Microbiology-Parasitology, Faculty of Medicine, National Autonomous University of Mexico (UNAM)", which is registered in the World Data Centre for Microorganisms (WDCM) database under the acronym LIH-UNAM WDCM817. Information on strains is available at the website [26].

\section{DNA extraction}

The biomass from each isolate was obtained by filtering the mycelial growth developed in GYE medium (glucose $2 \%$, yeast extract $1 \%$ ), and DNA was obtained as described by Reyes-Montes et al. [27].

\section{PCR}

The reaction was carried out utilizing the oligonucleotides reported by Guedes et al. [28] with the following modifications: in a $25-\mu \mathrm{L}$ final reaction volume, we used $30 \mathrm{ng}$ of genomic DNA, $2.0 \mathrm{mM} \mathrm{MgCl}, 200 \mu \mathrm{M}$ dNTPs (Applied Biosystems, Inc., Foster City, CA, USA), 1.0 U Taq polymerase (Applied Biosystems), and $50 \mathrm{pmol} / \mu \mathrm{L}$ of each oligonucleotide. The amplification program comprised one 3 -min cycle at $95^{\circ} \mathrm{C}$ followed by 351 min cycles at $95^{\circ} \mathrm{C}, 1 \mathrm{~min}$ at $55^{\circ} \mathrm{C}, 1 \mathrm{~min}$ at $72^{\circ} \mathrm{C}$, and a final 5-min cycle at $72^{\circ} \mathrm{C}$ to ensure full extension of all amplified products. The amplified products were analyzed in $1.5 \%$ agarose gel. Electrophoresis was conducted at $100 \mathrm{~V}$ in TBE $0.5 \times$ buffer. The molecular size standard employed was 100-bp DNA Ladder (Invitrogen, Carlsbad, CA, USA).

\section{RAPD-PCR}

Random amplification polymerase DNA (RAPD) H. capsulatum DNAs were amplified employing the oligonucleotides 1253 (5'-GTTTCCGCCC-3') and a double initiator, $1281 \quad\left(5^{\prime}\right.$ AACGCGCAAC-3') and 1283 (5'GCGATCCCCA-3') (Operon Technologies, Inc., Alameda, CA, USA) according to Kersulyte et al. [29] and Woods et al. [30]. The reaction was performed according to ReyesMontes et al. [27] and Taylor et al. [31]. Amplicons were observed by staining the gels with ethidium bromide (10 $\mu \mathrm{g} / \mathrm{mL}$ ). A 100-bp DNA Ladder (Invitrogen) was utilized as standard molecular size. Images of the gels were registered in a Synoptics Photodocumenter (Syngene, Cambridge, MA, USA). A dendrogram was constructed from the molecular profiles obtained to correlate the percentage of similarity among strains. The dendrogram was generated using the Unweighted pair group method with arithmetic mean (UPGMA), and Jaccard co-efficient was estimated from a band presence-and-absence matrix.

\section{Results}

\section{Case Studies}

The infection site is located in the town of Tamarindos, Ciudad Cardel, Veracruz state, in a histoplasmosis endemic zone (Figure 1). Average time for symptoms to appear was 7 to 20 days. Main clinical manifestations included fever, bouts of dry cough, chest pain, dyspnea with medium effort, shivering, diaphoresis, myalgias, arthralgias, headaches, weight loss, nausea, vomiting (these latter two symptoms are rare in this infection) $[32,33]$, and an overall deficient health state. The clinical forms of the disease and organs affected are listed in Table 1. Disseminated histoplasmosis was considered when patients had hepatosplenomegaly and elevated liver enzymes, especially alkaline phosphatase. In all cases, chest $\mathrm{x}$-rays and high-resolution CT scan showed micronodular images in both lungs. Moreover, in patients with disseminated histoplasmosis, the chest CT scan divulged bilateral retrocaval, prevascular, subcarinal, and hiliar adenopathies, and hepato- and splenomegaly.

Isolation and Identification of $\mathrm{H}$. capsulatum and detection of anti-H. capsulatum antibodies

Cytology of the specimens exhibited the yeast phase of the fungus. Only two isolates were obtained from different patients: LFD, clinical isolate (bronchial lavage), and EVP clinical isolate (sputum), which were totally identified based on inclusion criteria for the $H$. capsulatum (type B colonies) species and its characteristic macroand micromorphology. Serologic results were the following: PT, 1:32 to 1:256; ELISA, >1:320; $\mathrm{H}$ and $\mathrm{M}$ bands 
Table 1 Demographic and clinical data patients

\begin{tabular}{|c|c|c|c|c|c|c|c|}
\hline Case & Gender & $\begin{array}{l}\text { Age } \\
\text { (years) }\end{array}$ & Occupation & $\begin{array}{l}\text { Incubation period } \\
\text { (days) }\end{array}$ & $\begin{array}{l}\text { Time disease evolution } \\
\text { (days) }\end{array}$ & Clinical form & Organs affected \\
\hline 1 & M & 49 & Taxi driver & 7 & 25 & $\mathrm{PPH}$ & Lungs \\
\hline 2 & M & 27 & $\begin{array}{l}\text { Gas-station } \\
\text { attendant }\end{array}$ & 7 & 25 & $\begin{array}{l}\text { Disseminated } \\
\text { histoplasmosis }\end{array}$ & $\begin{array}{l}\text { Lungs, liver, and } \\
\text { spleen }\end{array}$ \\
\hline 3 & M & 46 & Shaman & 20 & 12 & $\begin{array}{l}\text { Disseminated } \\
\text { histoplasmosis }\end{array}$ & Lungs, liver \\
\hline 4 & $\mathrm{~F}$ & 36 & Home maker & 8 & 26 & $\begin{array}{l}\text { Disseminated } \\
\text { histoplasmosis }\end{array}$ & $\begin{array}{l}\text { Lungs, liver, and } \\
\text { spleen }\end{array}$ \\
\hline 5 & F & 11 & Student & 10 & 25 & $\begin{array}{l}\text { Disseminated } \\
\text { histoplasmosis }\end{array}$ & $\begin{array}{l}\text { Lungs, liver, and } \\
\text { spleen }\end{array}$ \\
\hline 6 & $\mathrm{~F}$ & 8 & Student & 10 & 25 & $\begin{array}{l}\text { Disseminated } \\
\text { histoplasmosis }\end{array}$ & $\begin{array}{l}\text { Lungs, liver, and } \\
\text { spleen }\end{array}$ \\
\hline
\end{tabular}

M, Male; F, Female; PPH, Primary pulmonary histoplasmosis.

were observed in ID, and Intradermoreaction (IDR) to histoplasmin ( $>5$-mm induration) was noted in all cases.

\section{Molecular Characterization of the Isolates}

Molecular identification of the isolates was confirmed by PCR on amplifying a specific 279 base-pair (bp) band corresponding to the codifying region for the $H$. capsulatum-immunodominant M-antigen gene [28] (Figure 2a).
Molecular characterization of the two clinical isolates of $H$. capsulatum from VZ was conducted oligonucleotides 1253 (figure 2b) and 1281 and 1283 (figures 2c and 2d) RAPD-PCR assays. The figure $2 \mathrm{~d}$ shows the molecular profiles of these two isolates, compared with those of the eight H.-capsulatum reference strains. The bands obtained were located in the 800 to 200-bp range (Figure

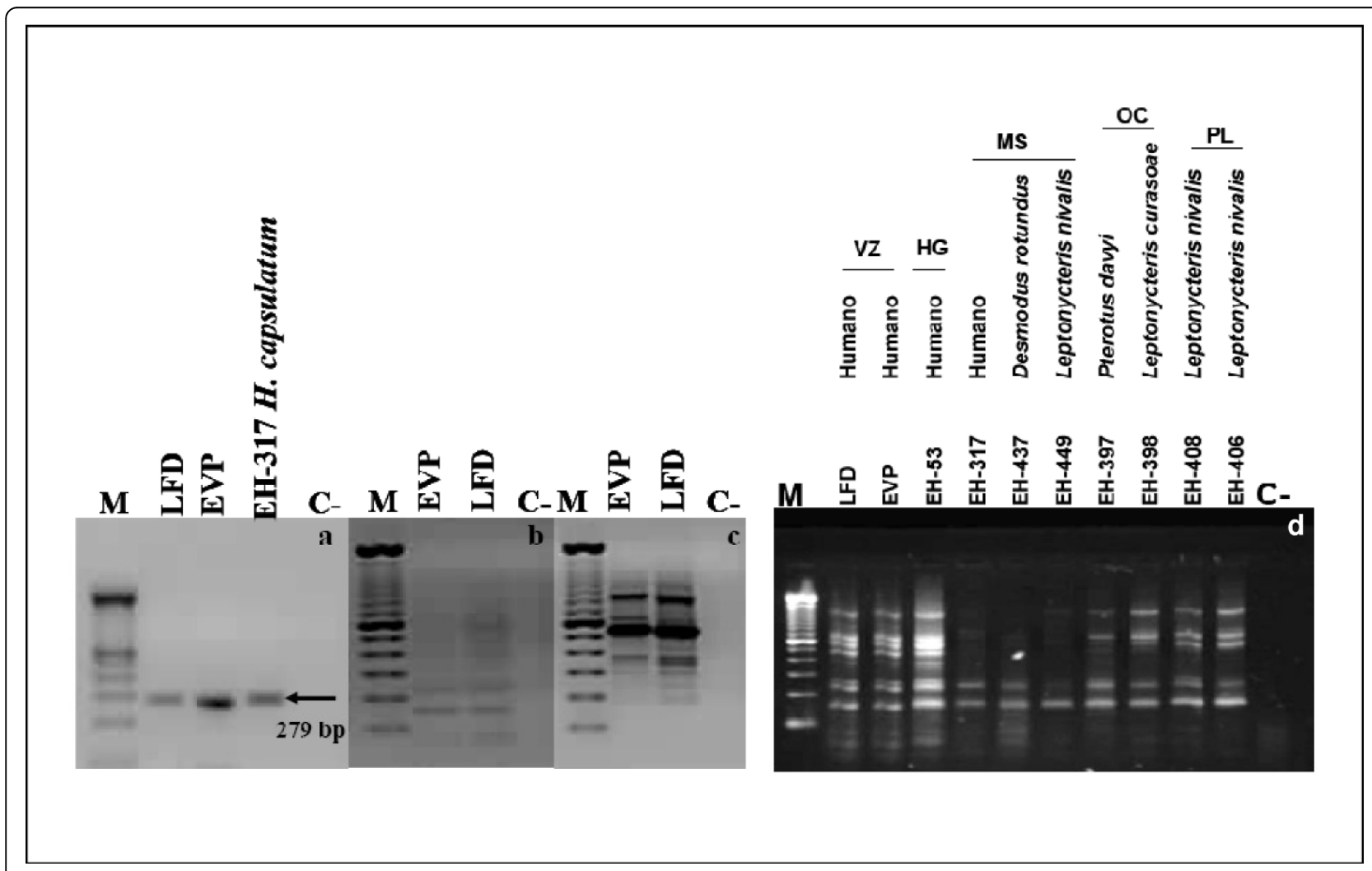

Figure 2 Identification and characterization of Histoplasma capsulatum isolates from Veracruz (VZ). (a) Identification of H. capsulatum isolates using Polymerase chain reaction (PCR) with the probe designed from the $\mathrm{M}$ antigen; $(\mathrm{b}$ and $\mathrm{c}$ ) characterization by Random amplification of polymorphic DNA-PCR (RAPD-PCR) of H. capsulatum isolates with 1253 (b) and the mixture of 1281 and 1283 oligonucleotides (c); M 100 bp DNA Ladder; LFD, EVP, and EH-317 H. capsulatum; C (-) reagent control. (d) RAPD-PCR DNA patterns obtained from H. capsulatum isolates LFD and EVP compared with isolated 8 reference strains from humans or bats from different geographical regions in Mexico. 
2d). Relatedness among isolates through the polymorphic DNA patterns was analyzed by using the UPGMA program to elaborate a dendrogram (Figure 3) and three groups, according to RAPD-patterns, were identified. Group I is made up of two subgroups: subgroup 1a, which includes VZ (LFD [bronchial lavage] and EVP [sputum]) isolates, and the EH-53 (HG) reference strain, which exhibited $100 \%$ similarity, while subgroup Ib comprised bat isolates from PL. Both subgroups are related at 85\% similarity. Group II comprises of EH-397 and -398 bat isolates from (OC) with $100 \%$ similarity between them. This group is related to group I with $82 \%$ similarity. Group III is made up of two subgroups: subgroup IIIa is formed by EH-317 and EH-437 bat isolates from MS, with a $100 \%$ similarity ratio, and subgroup IIIb consists of isolates from the State of Morelos (EH-449), which were $73 \%$ related to subgroup IIIa strains Finally, group III is related to the previous groups with $52 \%$ similarity.

\section{Discussion}

In Mexico, the first probable outbreak of histoplasmosis was described and recorded in a Public Health Acts ledger from the state of Nuevo León at the end of the $19^{\text {th }}$ century (ca. 1885) when certain clinical scenarios were described that led to the suspicion that there was an epidemic of this mycosis in mine workers from areas containing a large amount of bat guano. In 1943, Martínez-Báez reported the first proven case of histoplasmosis in Mexico, while the first officially described outbreak was observed in subjects who had entered into "El Refugio", an abandoned mine located in Lampazos, Nuevo León; both data were referred by AguirrePequeño [34].

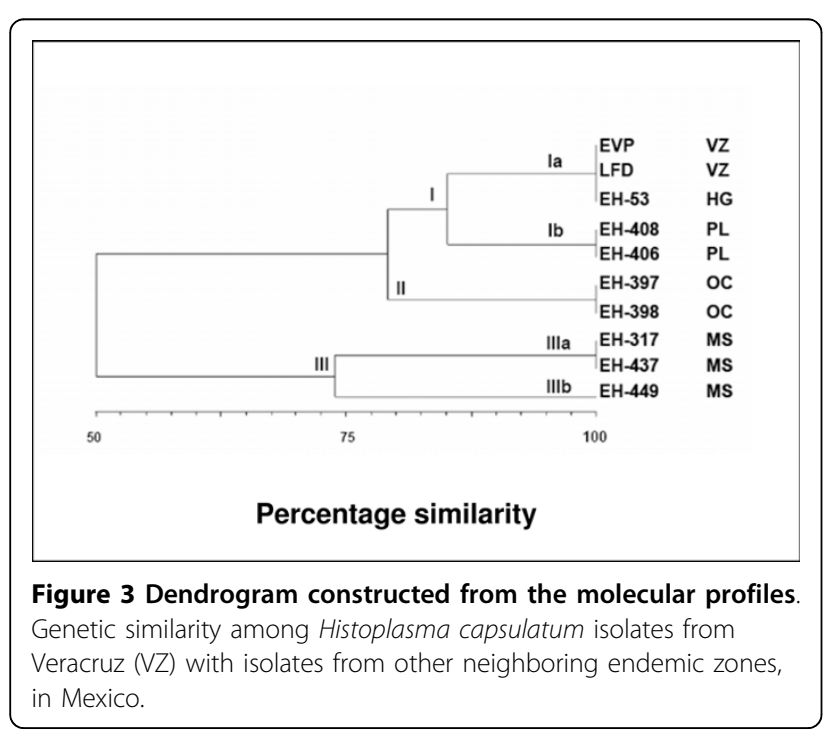

From studies by Aguirre-Pequeño [34] and GonzálezOchoa [9-13], histoplasmosis in Mexico is considered an occupational disease because a relationship has been established between severe Primary pulmonary histoplasmosis (PPH) in miners exposed to high concentrations of H.-capsulatum propagules from bat guano. Histoplasmosis outbreaks have reported with a death rate as high as $100 \%$ in affected individuals [18-20]. Despite that the number of histoplasmosis outbreaks continues to rise, there are no official records of the majority of these. The most recent outbreak reported occurred in Spring-Break student tourists in Acapulco between March and May 2001 [35]. During this outbreak, $H$. capsulatum was isolated from compost employed as fertilizers in ornamental plants at the hotel where the students stayed [17].

The results of our study show that the patients had acquired histoplasmosis in the town of Tamarindos, Ciudad Cardel, Veracruz (Figure 1). Patients' signs and symptoms were clearly associated with chest $\mathrm{x}$-ray images and chest CT scans. The etiological agent was clearly identified utilizing macro- and micromorphology and assessment of anti-Histoplasma antibodies, and IDR, and its identification was confirmed by PCR (Figure 2a). In addition, using RAPD-PCR, the two isolates were observed to possess the same polymorphic pattern based on their genetic material, indicating that the patients were infected with the same $H$. capsulatum strain prevalent at this site (Figures $2 \mathrm{~b}$ and $2 \mathrm{c}$ ).

In this study, five of the six patients developed disseminated histoplasmosis. The severity of the infection in these patients can be attributed to factors such as i) extreme physical effort, ii) inhalation of a large number of infectious propagules (when digging to find a treasure, the moving of the bat and bird excreta found at the infection site), iii) long exposure time (patients remained for 3 full days excavating and sleeping at the same site), iv) low socioeconomic status of the workers with severe nutritional and immunological deficiencies, and v) a probable high virulence of the strains present at the infection site. The EH-53 reference strain is highly virulent, proceeding from HG, Mexico, and isolated from a patient with fatally disseminated histoplasmosis. Although the molecular characterization of isolates was not carried out in full, $100 \%$ similarity (observed in the dendrogram) between the two VZ isolates and the $\mathrm{EH}-$ 53 strain (Figure 3), and the severity of the patients' clinical problems, could suggest the presence of the strain in this geographic area. Several authors have reported a high virulence rate of $H$. capsulatum strains in Mexico [10,11,18,20,36].

Molecular typification of the two isolates from this outbreak was compared with the polymorphic DNA patterns of strains collected from VZ-neighboring areas. 
EVP and LFD isolates presented 100\% similarity to the EH-53 HG strain (Figure 3), which was isolated in 1977; therefore, the two isolates are considered as probably the same strain. The EH-53 strain is included in the Lam A clade (forming a monophyletic group for Latin America) according to Kasanuga et al. [8]. Due to that these isolates were not characterized by four genes as utilized by Kasuga because we did not possess the appropriate primers, it was not possible to perform a definitive classification.

The Ciudad Cardel, La Antigua, Municipality, Veracruz (Figure 1), endemic zone where patients acquired the infection is located in the central coastal zone of the state of Veracruz at coordinates $19^{\circ} 22^{\prime}$ latitude North and $96^{\circ} 22^{\prime}$ longitude West, and at an altitude of $20 \mathrm{~m}$ above sea level. Its climate is warm with an average temperature of $25^{\circ} \mathrm{C}$. Average annual rainfall is 1,500 $\mathrm{mm}$. In this municipality, fauna is mainly comprised of rabbits, foxes, coyotes, armadillos, raccoons, and bats; reptiles such as rattlesnakes, migratory birds, and other birds are often found to be $H$. capsulatum reservoirs. The house where the patients slept was surrounded by trees in which bats and migratory birds roosted overnight. Maintenance of this strain in the environment, in the neighboring areas of both HG and VZ, could probably be explained by the very important role that bat guano plays in spreading $H$. capsulatum, as reported by Taylor et al. [16], in which the authors mention that $H$. capsulatum propagules can be dispersed at different distances. In general, it appears that bats are the ideal candidates for spreading $H$. capsulatum in both short, as well as in long, distances. The cave-colonizing behavior of bats, their ability to fly, and their habit of remaining in the same caves for long periods are important factors that explain the dynamics behind the dispersion of the fungus in nature. For example, infected bats can act as dispersers of the parasite and incorporate the fungus into new, favorable environments, possibly through cadavers [15]. Additionally, the wide diversity of the fauna present, which is characteristic of the infectious site, also contributes importantly to maintenance of $H$. capsulatum in the environment.

The therapeutic scheme administered to three patients was amphotericin B deoxycholate $(0.7 \mathrm{mg} / \mathrm{kg} /$ day every 7 days), and methylprednisone $(1 \mathrm{mg} / \mathrm{kg} /$ day every 7 days), prior to administering amphotericin $\mathrm{B}$, to avoid collateral effects; afterward, itraconazole $600 \mathrm{mg} /$ day was administered for 3 days, and finally, itraconazole $400 \mathrm{mg} /$ day was given every 12 weeks), while the remaining three patients were only administered itraconazole $(200 \mathrm{mg} /$ day every 12 weeks). Symptoms and lesions in all patients resolved. The symptomatology of the febrile respiratory disease is not specific for pulmonary histoplasmosis, and on occasion, a mistaken diagnosis is reached, with subsequent administration of the inappropriate treatment.

\section{Conclusions}

The two isolates were observed as possessing the same polymorphic pattern, indicating that the patients were infected with the same $H$. capsulatum strain prevalent at this site. It is important to remain updated on recent outbreaks of histoplasmosis and the manner of exposure to the fungi, as well as to emphasize molecular characterization of isolates located in this endemic zone. The severity of cases indicates that these strains are highly virulent, and it is probable that these isolates are prevalent in Hidalgo and Veracruz states. People residing in or visiting this endemic area should be aware of the health risks of histoplasmosis infection to which they might be subjected, to as well as health care personnel for them to exercise the necessary preventive measures.

\section{Author details}

'Laboratorio de Micología Médica, Depto. de Investigación en Virología, Instituto Nacional de Enfermedades Respiratorias (INER), Calzada de Tlalpan 4502, Sección XVI, Tlalpan,14080 México, D.F., México. ²Laboratorio de Micología Médica, Depto. de Microbiología, Escuela Nacional de Ciencias Biológicas (ENCB), Instituto Politécnico Nacional (IPN), México, D.F., México. ${ }^{3}$ Laboratorio de Biología Molecular de Hongos, Depto. de Microbiología y Parasitología, Facultad de Medicina, Universidad Nacional Autónoma de México (UNAM), Mexico City, Mexico. ${ }^{4}$ Laboratorio de Inmunología de Hongos, Depto. de Microbiología y Parasitología, Facultad de Medicina, (UNAM), Mexico City, Mexico. ${ }^{5}$ Departamento de Investigación en Epidemiología Clínica, Nacional de Enfermedades Respiratorias (INER), Calzada de Tlalpan 4502, Sección XVI, Tlalpan,14080 México, D.F., México.

\section{Authors' contributions}

BM Participated in study design and coordination and helped to draft the manuscript. MAM Participated in sequence alignment and drafted the manuscript. GP Performed the serologic tests and obtained the samples. AR Participated in the clinical studies and patient data case studies. MGF Conducted the molecular studies. MRR Performed and interpreted the molecular studies. MLT Assisted in characterization of isolates with reference strains. ALH Participated in clinical and case studies and performed data analysis. AC Obtained the samples and performed the data analysis. MEM Conceived of the study, participated in its design, and drafted the manuscript.

All authors read and approved the final manuscript.

\section{Competing interests}

The authors declare that they have no competing interests.

Received: 8 July 2009 Accepted: 8 September 2010

Published: 8 September 2010

\section{References}

1. Eissenberg LG, Goldman WE: Histoplasma variation and adaptative strategies for parasitism: new perspectives on histoplasmosis. Clin Microbiol Rev 1991, 4:411-421.

2. Eissenberg LG, Goldman WE: The interplay between Histoplasma capsulatum and its host cells. Clin Infect Dis 1994, 1:265-283.

3. Taylor ML, Granados J, Toriello C: Biological and sociocultural approaches of histoplasmosis in the State of Guerrero, Mexico. Mycoses 1996, 39:375-379.

4. Vincent RD, Goewert R, Goldman WE, Kobayashi GS, Lambowitz AM, Medoff $\mathrm{G}$ : Classification of Histoplasma capsulatum isolates by restriction fragment polymorphisms. J Bacteriol 1986, 65:813-818, 209-225. 
5. Spitzer ED, Lasker BA, Travis SJ, Kobayashi GS, Medoff G: Use of mitochondrial and ribosomal DNA polymorphisms to classify clinical and soil isolates of Histoplasma capsulatum. Infect Immun 1989, 57:1409-1412.

6. Keath EJ, Kobayashi GS, Medoff G: Typing of Histoplasma capsulatum by restriction fragment length polymorphisms in a nuclear gene. J Clin Microbiol 1992, 30:2104-2107.

7. Kasuga T, Taylor JW, White TJ: Phylogenetic relationships of varieties and geographical groups of the human pathogenic fungus Histoplasma capsulatum Darling. J Clin Microbiol 1999, 37:653-663.

8. Kasuga T, White TJ, Koening G, Mcewen J, Restrepo A, Castañeda E, Da Silva LC, Heins-VAccari EM, De Freitas RS, Zancopé-Oliveira RM, Zhenyu Q, Negroni R, Carter DA, Yuzuru M, Tamura M, Taylor ML, Miller GF, Poonwan N, Taylor JW: Phylography of the fungal pathogen Histoplasma capsulatum. Mol Ecol 2003, 12:3383-3401.

9. González-Ochoa A: Histoplasmosis primaria pulmonar aguda en la Republica Mexicana. Estudio de 74 casos. Rev Inst Salubr Enferm Trop 1959, 19:341-350.

10. González-Ochoa A: Peculiarities of the severe primary pulmonary histoplasmosis in this country. Gac Med Mex 1961, 91:5-11.

11. González-Ochoa A: Epidemiology of primary histoplasmosis in Mexico. Rev Inst Salubr Enferm Trop 1963, 23:65-80.

12. González-Ochoa A: Geography of deep mycoses. Rev Invest Salud Publica 1975, 35(1):85-96.

13. González-Ochoa A, Félix D: Geographic distribution of cutaneous reactivity to histoplasmin in Mexico. Rev Invest Salud Publica 1971, 31(2):74-77.

14. Ramón-García G, Peña-Alonso YR, Ontiveros-Nevares PG: Disseminated histoplasmosis in children. Bol Med Hosp Infant Mex 1993, 50:870-875.

15. Taylor ML, Pedroza-Séres M, Gámez-Aranda A, Toriello C: Retrospective serological study of histoplasmosis in Mexico. Mycoses 1993, 36:25-30.

16. Taylor ML, Chávez-Tapia CB, Rojas-Martínez A, Reyes-Montes MR, BobadillaDel Valle M, Zúñiga G: Geographical distribution of genetic polymorphism of the pathogen Histoplasma capsulatum isolated from infected bats, captured in a central zone of Mexico. FEMS Immunol Med Microbiol 2005, 45:451-458.

17. Taylor ML, Ruíz-Palacios GM, Reyes-Montes MR, Rodríguez-Arellanes G, Carreto-Binaghi LE, Duarte-Escalante E, Hernández-Ramírez A, Pérez A, Suárez-Alvarez R, Roldán-Arango YA, Romero-Martínez R, SahazaCardona JH, Sifuentes-Osornio J: Identification of the infectious source of an unusual outbreak of histoplasmosis, in a hotel in Acapulco, state of Guerrero, Mexico. FEMS Immunol Med Microbiol 2005, 45:435-441.

18. Vaca-Marín MA, Martínez-Rivera MA, Flores-Estrada JJ: Histoplasmosis en México, aspectos históricos y epidemiológicos. Rev Inst Nal Enferm Resp Mex 1998, 11:208-215.

19. Velasco-Castrejón O, González-Ochoa A: A primary pulmonary epidemia histoplasmosis in an abandoned mine. Mykosen 1977, 20:393-403.

20. Velasco-Castrejón O: La histoplasmosis pulmonar primaria en México. Rev Inst Nal Enferm Resp Mex 1998, 11:221-225.

21. Cozad GC, Larsh HW: A capillary tube agglutination test for histoplasmosis. J Immunol 1960, 85:387-390.

22. Kaufman L, Standard PG: Specific and rapid identification of medically important fungi by exoantigen detection. Annu Rev Microbiol 1987, 41:209-225.

23. Standard $P G$, Kaufman L: Specific immunological test for the rapid identification of members of the genus Histoplasma. J Clin Microbiol 1976, 3:191-199.

24. Ouchterlony $\mathrm{O}$, Nilsson LA: Immunodiffusion and immunoelectrophoresis. In Handbook of Experimental Immunology. Edited by: Weir DM. Oxford, UK: Blackwell Scientific Publications; 1978:1-19.44.

25. Voller $A$, Bidwell DE, Bartlett $A$ : The enzyme linked immunosorbent assay (ELISA). A guide with abstracts of microplate applications. London, UK: Dynatech Europe Laboratories, Inc 1979.

26. Histoplasmosis en México. Colección de cepas de Histoplasma capsulatum. 2002 [http://www.histoplas-mex.unam.mx], (links: - UNAMFacultad de Medicina, Depto. de Microbiología y Parasitología, Lab. de Inmunología de Hongos; - Instituto Nacional de Ciencias Médicas y Nutrición "Salvador Zubirán", Depto. de Infectología, Lab. de Microbiología Clínica; - Instituto Nacional de Enfermedades Respiratorias, Lab. de Microbiología Clínica.

27. Reyes-Montes MR, Bobadilla-Del Valle M, Martínez-Rivera MA, RodríguezArellanes G, Maravilla E, Sifuentes-Osornio J, Taylor ML: Relatedness analyses of Histoplasma capsulatum isolates from Mexican patients with AIDS-associated histoplasmosis is by using histoplasmin electrophoretic profiles and randomly amplified polymorphic DNA patterns. J Clin Microbiol 1999, 37:1404-1408.

28. Guedes HL, Guimâraes AJ, Muñiz M de M, Oizzini CV, Hamilton AJ, Peralta JM, Deepe GS Jr, Zancopé-Oliveira RM: PCR assay for identification of Histoplasma capsulatum based on the nucleotide sequence of the $M$ antigen. J Clin Microbiol 2003, 41:535-539.

29. Kersulyte D, Wood JP, Keath EJ, Goldman WE, Berg DE: Diversity among clinical isolates of Histoplasma capsulatum detected by polymerase chain reaction with arbitrary primers. J Bacteriol 1992, 174:7075-7079.

30. Woods JP, Kersulyte D, Goldman WE, Berg DE: Fast DNA isolation from Histoplasma capsulatum: methodology for arbitrary primer polymerase chain reaction based epidemiological and clinical studies. J Clin Microbiol 1993, 31:463-464.

31. Taylor ML, Chávez-Tapia CB, Reyes-Montes MR: Molecular typing of Histoplasma capsulatum isolated from infected bats, captured in Mexico. Fungal Genet Biol 2000, 30:207-212.

32. Mata-Essayag S, Colella MT, Roselló A, Hartung de Capriles C, Landaeta ME, Pérez de Salazar C, Magaldi S, Olaizola C, Calatroni MI, Garrido L: Histoplasmosis, A Study of 158 Cases in Venezuela, 2000-2005. Medicine 2008, 87:193-202.

33. Assi MA, Sandid MS, Baddour LM, Roberts GD, Walker RC: Systemic histoplasmosis. A 15-year retrospective institutional review of 111 patients. Medicine 2007, 86:162-169.

34. Aguirre-Pequeño E: Aislamiento de Histoplasma capsulatum del guano murciélago en cuevas del noroeste de México. Gac Med Mex 1959, 89:243-253.

35. Morgan J, Cano MV, Feikin DR, Phelan M, Monroy OV, Morales PK, Carpenter J, Weltman A, Spitzer PG, Liu HH, Mirza SA, Bronstein DE, Morgan DJ, Kirkman LA, Brandt ME, Igual N, Lindsley MD, Warnock DW, Haijeh RA, the Acapulco Histoplasmosis Working Group: A large outbreak of histoplasmosis among American travelers associated with a hotel in Acapulco, Mexico, Spring 2001. Am J Trop Med Hyg 2003, 69:663-669.

36. Velasco-Castrejón O, Fujigaki-Lechuga A: Importancia de la histoplasmosis pulmonar primaria en trabajadores de minas en México. Neumol Cir Torax 1984, 45:7-9.

\section{Pre-publication history}

The pre-publication history for this paper can be accessed here: http://www.biomedcentral.com/1471-2334/10/264/prepub

\section{doi:10.1186/1471-2334-10-264}

Cite this article as: Muñoz et al:: Molecular characterization of Histoplasma capsulatum isolated from an outbreak in treasure hunters. BMC Infectious Diseases 2010 10:264.

\section{Submit your next manuscript to BioMed Central and take full advantage of:}

- Convenient online submission

- Thorough peer review

- No space constraints or color figure charges

- Immediate publication on acceptance

- Inclusion in PubMed, CAS, Scopus and Google Scholar

- Research which is freely available for redistribution 